JSI 9 (1) (2020)
Jurnal Sastra Indonesia
UNNES

\title{
GAYA HIDUP HEDONIS TOKOH-TOKOH DALAM NOVEL ANTOLOGI RASA KARYA IKA NATASSA (KAJIAN SOSIOLOGI SASTRA)
}

\section{Inayatul Khoiriyah ${ }^{\bowtie 1}$}

Program Studi Sastra Indonesia, Jurusan Bahasa dan Sastra Indonesia, Fakultas Bahasa dan Seni, Universitas Negeri Semarang, Indonesia

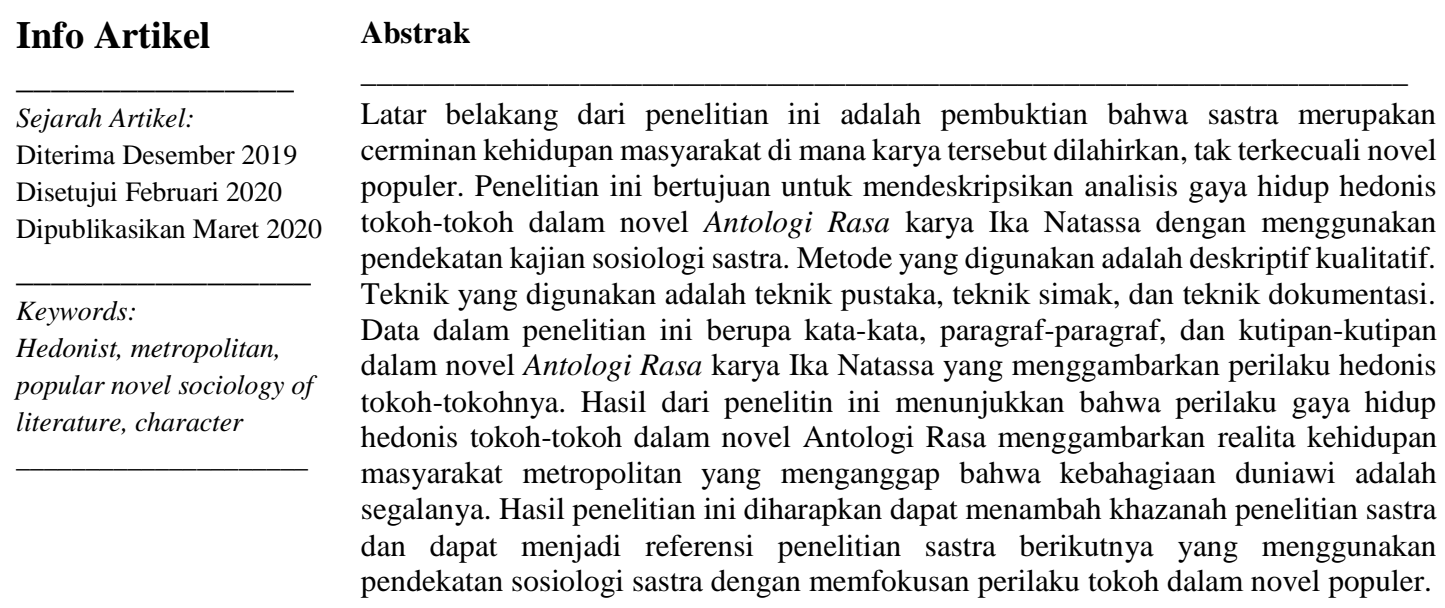

\begin{abstract}
The background of this study is proof that literature is a reflection of the communiy life of where the literature was born, including popular novels. This study aims to describe the hedonic lifestyle analysis of the figures in the novel Antologi Rasa by Ika Natassa by using the approach of the study of literary sociology. The method used is descriptive qualitative. The technique used is library techniques, reding techniques, and documentation techniques. The data in this study are in the form of words, paragraphs, and excerpts in the novel Antologi Rasa by Ika Natassa that illustrates the hedonic behavior of the characters. The results of this study show that the hedonic lifestyle behaviors of the characters in the Antologi Rasa illustrate the realities of metropolitan life which assume that worldly happiness is everything. The results of this study are expected to add to the treasury of literary research and can be a reference for the next erary research that uses a sociological approach to literature by focusing on the behavior of characters in popular novels.
\end{abstract}

(C) 2020 Universitas Negeri Semarang

Alamat korespondensi:
Gedung B1 Lantai 1 FBS Unnes
Kampus Sekaran, Gunungpati, Semarang, 50229
E-mail: inavatulkhoirivah2@students.unnes.ac.id

ISSN 2252-6315

E-ISSN 2685-9599 


\section{PENDAHULUAN}

Karya sastra merupakan cerita rekaan yang dihasilkan melalui proses kreatif dan imajinatif pengarang berdasarkan apa yang dilihat, dialami, dan dirasakannya dalam kehidupan nyata. Hal yang menjadi pokok dari karya sastra adalah manusia dan kehidupannya dengan menggunakan bahasa sebagai medium penyampaiannya. Karya sastra sebagai representasi dari realita kehidupan memiliki hubungan yang erat dengan latar budaya di mana karya tersebut dilahirkan. Hal itu juga diungkapkan Damono (dalam Tyas, 2018) bahwa karya sastra merupakan cerminan kehidupan sosial yang ada pada masyarakat tertentu pada masanya.

Karya sastra lahir di tengah-tengah masyarakat sebagai hasil imajinasi pengarang serta refleksinya terhadap gejala-gejala sosial di sekitarnya. Akan tetapi, karya sastra tidak hadir dalam kekosongan budaya (Pradopo, 2001). Dengan demikian, karya sastra tidak akan lahir tanpa adanya budaya yang tercipta dalam suatu lingkungan masyarakat. Karya sastra lahir sebagai cerminan kehidupan yang membudaya dalam lingkungan sosial masyarakat.

Salah satu karya sastra yang lahir sebagai hasil cerminan kehidupan sosial pada masyarakat tertentu adalah novel. Menurut Salfia (2015), novel adalah media penuangan pikiran, perasaan, dan gagasan penulis dalam merespon kehidupan di sekitarnya. Novel lahir atas dasar keinginan penulis atau pengarang untuk mendokumentasikan apa yang dilihat, dialami, dan dirasakannya dalam kehidupan nyata. Banyak permasalahan dalam kehidupan yang akhirnya didokumentasikan dalam sebuah novel. Tak hanya permasalahan, budaya-budaya yang lahir dari suatu kelompok masyarakat juga banyak yang akhirnya direpresentasikan oleh sebuah novel. Satu diantaranya adalah budaya hidup bergaya hedonis yang makin jelas terlihat dalam masyarakat terutama yang tinggal di kotakota metropolitan.

Jenis novel yang mengisahkan kehidupan beserta permasalahan masyarakat kota metropolitan adalah novel metropop. Hampir semua novel-novel bergenre metropop bercerita mengenai masyarakat urban menengah dan berlatar di kota-kota metropolitan dengan menampilkan sisi-sisi kehidupan hedonis tokohtokohnya.

Gaya hidup hedonis memandang bahwa hal-hal yang bersifat kemewahan duniawi adalah segalanya. Hal tersebut sesuai dengan pendapat Susianto (dalam Sarlina, 2016) yang menyatakan bahwa gaya hidup hedonis adalah pola hidup yang mengarahkan semua aktivitasnya hanya untuk mencari kesenangan sebagai tujuan hidupnya.

Salah satu novel bergenre metropop yang terlihat jelas menampilkan kehidupan hedonis tokoh-tokohnya adalah novel berjudul Antologi Rasa karya Ika Natassa. Novel Antologi Rasa karya Ika Natassa adalah salah satu novel yang menceritkan problematika kehidupan kelas menengah di kota metropolitan. Perilaku usia dewasa dengan gaya hidup hedonismenya tergambar pada setiap bab dalam novel ini. Gaya hidup hedonis yang merupakan cerminan dari gaya hidup masyarakat metropolitan dapat ditemukan dalam kehidupan tiga tokoh yang menjadi pusat penceritaan dalam novel ini, yaitu Keara, Harris, dan Rully.

Antologi Rasa menarik untuk diteliti dengan melihat bagaimana nyatanya novel ini menggambarkan realita kehidupan manusia dewasa usia akhir dua puluhan yang menentap di kota metropolitan dengan segala macam gaya hidup hedonisnya. Tokoh-tokoh yang menjadi pusat penceritaan dalam novel Antologi Rasa yang tidak lagi memikirkan masalah finansial menjadikan perilaku hedonis sebagai sumber mendapatkan kebahagiaan. Belanja barangbarang mewah, clubbing, jalan-jalan ke luar negeri, menonton konser kelas dunia di barisan paling depan, dan sederet perilaku hedonis lain seakan menjadi kebutuhan pokok yang harus mereka penuhi.

Tokoh-tokoh dari kelas menengah atas yang dimunculkan dalam novel Antologi Rasa ini adalah cerminan dari realita kehidupan masyarakat metropolitan yang hidup dengan segudang masalah yang pelik lagi kompleks. Di balik suksesnya tokoh di usia muda, karier yang diidamkan banyak orang dari kalangan bawah, gaji yang bisa digunakan untuk setidaknya sekali dalam sebulan dapat duduk bersila di Marina Bay Sands, dan hidup serba mewah tak lantas membuat semua menjadi mudah. Ika Natassa secara gamblang menegaskan bahwa hidup sebetulnya tidak pernah baik-baik saja sekalipun berbagai pencapaian berhasil dipeluk.

Berdasarkan pemaparan di atas, penulis menjadikan novel berjudul Antologi Rasa sebagai objek dalam penelitian ini. Penulis ingin meneliti sejauh mana novel berjudul Antologi Rasa ini dapat mencerminkan persoalan dalam kehidupan nyata. Gaya hidup hedonis tokoh dengan usia akhir dua puluhan yang hidup di kota metropolitan menjadi fokus dalam penelitian ini.

Pendekatan sosiologi sastra dipandang sesuai untuk digunakan sebagai dasar dalam 
penelitian ini. Seperti yang dikemukakan oleh Lurenson dan Swingewood (dalam Akbar, dkk., 2013), sosiologi sastra sangat sesuai untuk digunakan dalam penelitian yang memandang karya sastra sebagai dokumen sosial yang di dalamnya merupakan refleksi situasi pada masa sastra tersebut diciptakan, penelitian yang mengungkap sastra sebagai cermin situasi sosial penulisnya, dan penelitian yang menangkap sastra sebagai manifestasi peristiwa sejarah dan keadaan sosial budaya.

Berdasarkan latar belakang tersebut dapat dirumuskan tujuan dari penelitian ini adalah 1) mendeskripsikan unsur penokohan dalam novel Antologi Rasa karya Ika Natassa; dan 2) mendeskripsikan perilaku gaya hidup hedonis tokoh-tokoh dalam novel Antologi Rasa.

Penelitian terdahulu yang berkaitan dengan penelitian ini diantaranya adalah penelitian yang dilakukan Harum (2017) dengan judul "Konsep Maskulin dalam Karya Metropop Antologi Rasa Karya Ika Natassa", Frannanda, dkk. (2018) "Hedonisme dalam Novel Metropop Cewek Matre Karya Alberthiene Endah", Tyas (2018) "Analisis Sosiologi Karya Sastra terhadap Novel Suti Karangan Sapardi Djoko Damono", Cinta (2014) "Analisis Wacana Novel Antologi Rasa dan Gaya Hidup Hedonisme (Studi Deskriptif Kualitatif Mengenai Gaya Hidup Hedonisme yang Direpresentasikan dalam Novel Antologi Rasa Karya Ika Natassa)", Margaretha Ervina Sipayung (2016) yang berjudul "Konflik Sosial dalam Novel Maryam Karya Okky Madasari: Kajian Sosiologi Sastra", Nur Hastuti (2018) yang berjudul "Novel Bumi Manusia Karya Pramoedya Ananta Toer Kajian Sosiologi Sastra", Candra Rahma Wijaya Putra (2018) yang berjudul "Cerminan Zaman dalam Puisi (Tanpa Judul) Karya Wiji Thukul: Kajian Sosiologi Sastra", Rizqi Dwi Hasfian (2018) yang berjudul "Potret Kemiskinan dalam Naskah Drama Kampung Kardus Karya Gepeng Nugroho (Kajian Sosiologi Sastra)."

\section{METODE PENELITIAN}

Penelitian ini menggunakan pendekatan sosiologi sastra dengan metode deskriptif kualitatif. Data dalam penelitian ini berupa katakata, paragraf-paragraf, dan kutipan-kutipan dalam novel Antologi Rasa karya Ika Natassa yang menggambarkan perilaku hedonis tokohtokohnya. Sumber data dalam penelitian ini ialah novel berjudul Antologi Rasa karya Ika Natassa yang diterbitkan oleh Penerbit Gramedia Pustaka Utama cetakan ke-24, Juli 2019 yang terdiri atas 344 halaman. Teknik pengumpulan data yang digunakan dalam penelitian ini adalah teknik pustaka, teknik simak, dan teknik dokumentasi. Teknik pustaka digunakan untuk meneliti sumber-sumber tertulis, dalam penelitian ini adalah novel berjudul Antologi Rasa karya Ika Natassa. Teknik simak dilakukan untuk menyimak bahasa tulis dalam meneliti gaya hidup tokoh-tokoh dalam novel Antologi Rasa karya Ika Natassa. Teknik dokumentasi dilakukan dengan mencatat bagian-bagian teks dalam novel yang menggambarkan perilaku gaya hidup hedonis tokoh. Hasil pendokumentasian digunakan sebagai sumber data. Data yang diperoleh selama pendokumentasian disertakan kode sumber datanya untuk mengecek ulang terhadap sumber data ketika diperlukan dalam rangka analisis data.

\section{HASIL DAN PEMBAHASAN}

Hasil penelitian yang dipaparkan meliputi 1) unsur penokohan dalam novel Antologi Rasa karya Ika Natassa; dan 2) perilaku gaya hidup hedonis tokoh-tokoh dalam novel Antologi Rasa.

\section{Unsur Penokohan dalam novel Antologi Rasa Keara}

Keara merupakan salah satu tokoh dalam novel Antologi Rasa yang menjadi pusat penceritaan. Keara digambarkan sebagai gadis berusia akhir dua puluhan dari kalangan atas yang hidupnya serba berkecukupan. Hidup di kota metropolitan sangat memengaruhi gaya hidupnya. Hobi belanja, clubbing, dan makan di tempat-tempat mewah adalah beberapa kebiasaan yang mengarah pada gaya hidup hedonis. Hal tersebut dibuktikan dalam kutipan berikut.

(1) “...Dan malam itu, di tengah-tengah obrolan kami, ketika aku menyaksikan dia makan dengan nikmat di warung sederhana di pinggir jalan yang takkan mungkin kudatangi seumur hidupku kalau bukan karena dia,..." (halaman 206).

(2) "Hari Sabtu gini ya, Rul, gue tuh 'ngantor'-nya di Grand Indonesia, bukan busuk di kantor kaya begini." (halaman 141).

Seperti yang kita tahu, Grand Indonesia merupakan kompleks multiguna di kawasan Hotel Indonesia yang terdiri atas gedung perkantoran, apartemen, dan pusat perbelanjaan. Banyak major anchor dan merek lokal yang memenuhi tiap lounge yang disewakan. Grand Indonesia merupakan surga bagi penggila belanja, termasuk juga Keara. Bagi Keara, bekerja hanyalah pengisi waktu diantara akhir 
pekan. Dan akhir pekan akan digunakan Keara untuk berkegiatan sesuka hatinya, seperti berbelanja dan pergi ke tempat-tempat hiburan lainnya.

Kesukaan Keara pada dunia malam dibuktikan dalam kutipan berikut.

"Di tengah-tengah dentuman musik, ratusan orang yang memadati Zirca malam ini, hawa pengap parfum bercampur keringat, asap rokok, dan alkohol, Pete Tong dan John Digweed, dan Paull Oakenfold yang berlombalomba menampar-nampar gendang telingaku, harusnya aku bahkan tidak bisa mendengar suara di kepalaku sendiri." (halaman 69).

Fotografi merupakan hobi lain Keara selain belanja, clubbing, dan makan di tempattempat mewah. Meski tampak sebagai hobi yang dimiliki kebanyakan orang, tetapi hobi fotografi yang dimiliki Keara juga mengharuskannya menghabiskan banyak uang yang dimilikinya. Peralatan fotografi yang dimilikinya bukan seperti orang yang hanya menjadikan fotografi sebagai hobi, tetapi seperti seorang profesional yang menjadikan fotografi sebagai profesi. Hal tersebut dibuktikan dengan kutipan berikut.

"Keara, kalau sanggup beli kamera dan peretelan lensa lo itu, nggak usah sok mengeluh ke gue tiket F1 itu kemahalan, ya." (halaman 17).

Dari kutipan tersebut, sebelumnya telah dijelaskan bahwa harga tiket untuk bisa menonton F1 secara langsung berkisar antara belasan hingga puluhan juta rupiah. Jika dibandingkan dengan peralatan fotografi yang dimiliki Keara tentunya uang yang dihabiskannya cukup banyak hanya untuk memuaskan akan kesenangannya pada fotografi.

Selain sisi hedonis yang melekat dalam tokoh Keara, Keara sebenarnya adalah gadis yang pintar juga memiliki paras yang cantik. Ia adalah lulusan dari New York University. Meski tidak pernah memperlihatkan kepintarannya, tetapi Keara selalu memiliki pemikiranpemikiran yang membuat orang yang mendengarnya tercengang. Contohnya saat ada rapat dadakan di Sabtu pagi dengan tim dari Wymann Parrish yang Keara sama sekali tidak ada persiapan. Meski demikian, dia bisa menemukan ide cemerlang untuk permasalahan yang membuat akhir pekannya berantakan itu. Hal tersebut dibuktikan dalam kutipan berikut.
(1) "Guys, guys, I was talking to Keara here just now and I think she has a pretty good idea on how we should approach this. Key, if you may? Gue cuma bisa bengong, beneran bengong yang tentunya gue kamuflase dengan memasang tampang dan tatapan serius saat kalimat demi kalimat penuh kata-kata dewa seperti revenue pool, competitive differentiation, dan predefined industry targeting meluncur dari bibir Keara...." (halaman 142).

(2) Hari ini, dua kali Keara sukses mengagetkan gue. Kejadian di ruang rapat tadi satu. Gue tahu dia nggak bodoh, lulus NYU nggak mungkin hasil nyogok, kan." (halaman 144).

\section{Harris}

Harris juga merupakan tokoh dalam novel Antologi Rasa yang menjadi pusat penceritaan. Harris adalah laki-laki berusia tiga puluh tahun yang memiliki sifat playboy. Sama seperti Keara, Harris bisa dikatakan sebagai salah satu cerminan masyarakat metropolitan dengan segala macam gaya hedonisnya. Hal tersebut dibuktikan dalam beberapa kutipan berikut.

(1) "Harris Risjad, 30 tahun, laki-laki paling jantan se-Jakarta (seJabodetabek dan Bandung lebih tepatnya, tapi gue nggak perlu bragging, silakan konfirmasi ke semua perempuan yang ada di phonebook gue)...." (halaman 32).

(2) ...Gue memang tadi curi-curi BBMan. Nggak dengan semuanya, cuma dengan Kinar. Hey can you blame me? Gue dicuekin seharian, Kinar "tersedia", masa gue tolak.

"Kinar, ya? Atau Luna? Atau Sophie? Idih, ngapain juga gue ngabsen cewekcewek lo gini." (halaman 56).

(3) "Yo know what, Risjad, kalau lagi nggak berusaha tebar pesona setengah mati, elo itu adorable juga, ya." Kataku tersenyum padanya.

"Sayangnya gue udah tahu aja kalo elo itu PK," tawaku. (halaman 68).

(4) "Tapi gue jauh dari definisi pecundang sebenarnya. Ini bukan sekadar pembelaan diri gue ya, gue juga nggak perlu membuktikan ke orang-orang bahwa gue pantas dikejar-kejar semua perempuan di luar sana. Everyone of them wants a piece of this. Termasuk 
satu perempuan cantik, yang tadi meminjam lighter dari gue dan sekarang sedang merokok bareng gue di sini...." (halaman (153).

Dari beberapa kutipan di atas, terlihat bahwa Harris adalah tokoh laki-laki dalam novel Antologi Rasa yang memiliki sifat playboy. Dengan ketampanan dan uang yang dimilikinya itu, Harris bisa dengan mudah menaklukan setiap wanita cantik yang ditemuinya, kecuali Keara. Harris memang tergila-gila dengan Keara sejak kali pertama mereka bertemu di lift saat hari pertama mereka bekerja. Tapi sayangnya, Keara tidak pernah termakan rayuannya Harris. Meski demikian, Harris tetap menjadikan Keara sebagai wanita yang suatu saat berharap bisa ditaklukkan. Hal tersebut diperkuat dengan kutipan berikut.

"Sini gue ajarin sesuatu. Setiap lakilaki, betapapun berengseknya, betapapun sudah tidak terhitung lagi berapa perempuan yang sudah dia tiduri, seperti gue ini, pasti punya satu perempuan yang dia anggap sebagai gunung Everest-nya.

Gini deh gampangnya: satu perempuan yang sebenarnya dia cintai setengah mati di luar semua yang sudah dia banged itu. The ono is not just a statistic. Buat gue, perempuan itu Keara." (halaman 154).

\section{Rully}

Rully adalah sahabat Keara dan Harris, juga merupakan pusat penceritaan dalam novel Antologi Rasa ini. Rully digambarkan sebagai sosok lelaki yang baik. Tidak seperti Harris yang suka menggoda perempuan, Rully adalah lelaki alim yang tidak menjadikan perempuan sebagai objek permainannya.

Selain digambarkan sebagai a good husband in the future dan juga seorang workaholic, Rully sangat suka berolahraga. Baginya, olahraga adalah cara dia untuk melepaskan segala lelah setelah seharian bekerja. Karena kecintaannya terhadap olahraga, Rully sangat ingin menjadi atlet. Tapi dia sadar, bahwa menjadi atlet di Indonesia tidak akan membuat dia menjadi kaya. Menjadi atlet di Indonesia tidak akan membuat dia memiliki apa yang seharusnya dimiliki seorang pria.

$$
\text { "Gue cuma ingin jadi atlet, Key." }
$$

"Kalau lo nanya gue, apakah gue puas dengan pekerjaan gue sekarang, mungkin jawabannya sama dengan elo, Key. Ini cuma sesuatu yang harus gue lakukan...."

"Jadi atlet di sini nggak bisa bikin gue beli mobil yang sekarang terparkir di luar itu, Key. A man has to do what a man has to do, right?" (halaman 47).

\section{Perilaku Gaya Hidup Hedonis Tokoh-Tokoh dalam Novel Antologi Rasa Aktivitas}

Perilaku hedonis dalam novel Antologi Rasa ini dapat terlihat dari bagaimana tokohtokohnya menggunakan uangnya untuk memuaskan perilaku konsumtifnya. Data yang ditemukan berkaitan dengan perilaku konsumtif sebagai aspek aktivitas dalam perilaku gaya hidup hedonis adalah sebagai berikut.

"....Ya sebenarnya hidup kami di bank berskala internasional ini nggak susah-susah amat sampai harus makan mi instan tiap hari, tapi di saat satu-satunya cara untuk tidak menjedutkan kepala ke dinding adalah terbang ke Jakarta setiap weekend (yang harga tiket pesawatnya sendiri paling murah satu juta pulangpergi), jadi mending nggak usah nongkrong tiap hari di mal ecek-ecek kota itu deh daripada nggak bisa pulang ke Jakarta dan belanja sampai bangkrut. (halaman 19).

Gaya hidup hedonis dengan menghabiskan uang jutaan rupiah demi dapat memuaskan keinginan tampak pada tokoh Keara melalui kutipan penceritaan di atas. Pulang-pergi pedalaman Sumatra-Jakarta tiap akhir pekan tentu memerlukan biaya yang tidak sedikit. Jika si tokoh mau menahan keinginannya untuk tidak pulang ke Jakarta setiap akhir pekan, tentu uang yang dihabiskan selama perjalanan dapat ditabungnya untuk memenuhi kebutuhan lain yang lebih penting.

Setelah lima hari penuh bekerja dan hanya ada dua hari di akhir pekan untuk bisa menikmati kesenangan hidup yang sempat ditinggalkannya itu membuat tokoh-tokoh dalam novel Antologi Rasa rela merogoh kocek lebih dalam demi mendapatkan transportasi yang nyaman untuk pulang-pergi dari daerah sampai ke Jakarta. Hal yang dilakukan tokoh-tokoh tersebut merupakan cerminan dari realita kehidupan di mana masyarakat yang memiliki 
keadaan finansial baik bahkan berlebih pasti tidak akan segan-segan menghabiskan uangnya demi mendapatkan kenyamanan selama perjalanan dan bepergian. Meski tidak semua, akan tetapi masyarakat metropolitan cenderung lebih memilih menggunakan pesawat untuk bepergian karena alasan waktu, dan sebagainya. Padahal, seperti yang kita tahu bahwa tiket pesawat tidaklah murah. Tapi demi mendapatkan kenyamanan dan keefisienan waktu, orang-orang yang memiliki finansial lebih tidak akan mempermasalahkan berapa uang yang dihabiskannya demi mendapatkan kesenangan yang diinginkan.

"Satu malam sepulang dari kantor, ketika kami sedang membunuh kepenatan bareng di Canteen Pacific Place. Dua gelas white wine, pesto chicken wrap di piringku, fetuccini di piring sahabatku itu." (halaman 25).

Kutipan novel di atas merupakan bukti lain yang menandakan tokoh dalam novel Antologi Rasa dalam hal ini Keara memiliki gaya hidup hedonis terlihat dari pilihan tempat makan dan makanan yang dipesannya.

Canteen Pacific Place benar-benar ada dalam kehidupan nyata. Canteen Pacific Place adalah salah satu restoran mahal yang beralamat di J1. Jendral Sudirman, Jakarta Selatan. Hanya orang-orang dari kelas menengah ke atas yang berani masuk dan memesan makanan di tempat ini. Kisaran harga menu-menu di restoran ini rata-rata mulai dari $\mathrm{Rp} 150.000,00$ s.d Rp500.000,00.

Selain sebagai pemenuhan hasrat konsumtif, ternyata makan di tempat-tempat yang tidak semua orang bisa masuk, bagi masyarakat metropolitan yang berperilaku hedonis merupakan salah satu upaya untuk menunjukkan eksistensinya sebagai masyarakat dari kelas tertentu. Hal tersebut diperkuat dengan kutipan berikut.

"....Rese nih cewek-cewek kantor pada mau ke Tanah Abang."

"Kenapa lo nggak ikutan ke Tanah Abang juga?"

"Dan berdesak-desakan dengan rakyat jelata itu? Elo kenal gue nggak sih?"

Gue tertawa. "Ya udah mau makan di mana?"

Dia membawa gue ke Le Seminyak di Pacific Place,...." (halaman 155).

\section{Minat}

Salah satu perilaku dari gaya hidup hedonis adalah memiliki minat yang sangat besar terhadap hobi yang dimiliki atau hal yang disenanginya hingga rela menghabiskan uang belasan bahkan puluhan juta demi menjadi bagian dari hobi atau minat dari objek yang disenanginya itu.

"Yours truly here, me, menghabiskan uang seharga satu sepeda motor, aku harus sekuat tenaga melawan hasrat mengantukkan kepala ke dinding setiap mengingat angka itu, untuk membeli tiket pesawat, dan terutama untuk membeli tiket F1 agar dia bisa menonton dari jarak dekat dan merasakan langsung desingan mesin yang memekakan telinga...." (halaman 16).

Kutipan novel di atas adalah bagian milik Keara. Keara, sebagai salah satu pusat penceritaan dalam novel Antologi Rasa rela menghabiskan uang seharga satu sepeda motor demi dapat ikut menonton F1 yang diadakan di Singapura bersama rekan kerjanya. Dikutip dari www.oto.com, harga satu sepeda motor berkisar dari belasan juta hingga puluhan juta rupiah.

Dalam kehidupan nyata, hal yang dilakukan Keara tersebut sering kali kita jumpai dalam masyarakat yang tinggal di kota metropolitan. Masyarakat metropolitan apalagi yang termasuk dalam kelas menengah ke atas dan memiliki akses yang mudah untuk mencapai hal yang diinginkan tidak akan segan-segan mengeluarkan uang lebih demi mendapatkan hal yang disenanginya.

Pada kasus ini, kesenangan akan sebuah hobi atau objek tertentu dapat menyebabkan gaya hidup hedonis akibat dari perilaku konsumtif yang dilakukannya. Masyarakat kota metropolitan yang tidak lagi berurusan dengan masalah finansial, tidak lagi peduli berapa uang yang dihabiskanya demi menjadi bagian dari halhal yang disenangi. Belasan juta hingga puluhan juta uang yang dihabiskan tokoh Keara dan temannya demi menjadi bagian dari pembuatan sejarah balapan F1 di Singapura dimaksudkan demi mendapatkan kepuasan dan kesenangan duniawi.

\section{Opini}

Gaya hidup hedonis dapat terlihat dari bagaimana tanggapan yang diberikan tokoh dalam merespon atau menghadapi hal-hal yang menyangkut dengan dirinya. Tokoh-tokoh dalam novel Antologi Rasa dengan konflik-konflik yang dialaminya menyebabkan mereka 
membutuhkan tempat pelarian untuk menjaga kewarasannya. Dengan menghabiskan uang dan sederet aktivitas hedonis lainnya dilakukan oleh tokoh-tokoh sebagai respon atas masalahmasalah yang menghampiri dirinya. Mereka menganggap bahwa dengan melakukan kegiatan yang mereka senangi penderitan yang sedang mereka alami akan pergi seiring dengan seberapa banyak uang yang dikeluarkannya.

"But hey, what do you expect?

My head is a fucking crime scene right now.

And the first thing that it does is robbing my bank account." (halaman 63)

Kutipan di atas adalah salah satu opini dari tokoh dalam novel Antologi Rasa ketika sedang tiba-tiba mengalami permasalahan. Keara yang saat itu sedang berada di Singapura mendapat kabar bahwa orang yang dicintainya, yaitu Rully mengalami kecelakaan. Usai mendengar kabar tersebut, Keara sangat merasa tertekan dan merasa hidupnya tidak dibutuhkan oleh Rully. Maka, untuk menghindari penderitaan yang jika dibiarkan akan membuat Keara kehilangan kewarasannya, hal yang terlintas dipikirannya adalah menguras tabungannya dengan berbelanja barang-barang mewah supaya dapat melupakan permasalahannya meski hanya sejenak.

Opini tokoh Keara yang bersifat hedonis tersebut juga dapat kita temukan dalam realita kehidupan. Orang-orang yang bergaya hidup hedonis akan sebisa mungkin menghindari penderitaan dengan melampiaskannya pada halhal yang membuatnya mendapatkan kesenangan. Berbelanja merupakan salah satu kegiatan yang dinilai dapat mengalihkan penderitaan yang sedang dialaminya. Apalagi tempat berbelanjanya dapat memberikan suatu kesenangan yang dibutuhkan.

"We're in Singapore, Ris. This heaven for shoppers. Berisik deh lo itu, suka-suka gue dong mau belanja apa, duit duit gue." (halaman 62).

Berdasarkan kutipan di atas, menurut Keara Singapura merupakan tempat yang cocok untuk berbelanja apalagi berbelanja karena menghindari permasalahan yang sedang dialaminya. Orchard Road Singapore merupakan latar di mana adegan tersebut terjadi. Orchad Road adalah boulevard sepanjang 2,2 kilometer yang merupakan pusat pertokoan dan hiburan di Singapura. Banyak merek-merek terkenal berjajar di sepanjang Orchad Road. Mereka yang menjadikan belanja sebagai upaya untuk lari dari permasalahan yang sedang dihadapinya tidak akan menghitung berapa uang yang sudah dikeluarkannya dan barang apa saja yang dibelinya. Mereka menganggap bahwa semua itu tidak ada artinya asalkan penderitaan atau permasalahan yang dihadapinya segera pergi.

\section{PENUTUP \\ Simpulan}

Gaya hidup hedonis kini telah menjadi tren dalam kalangan masyarakat, terutama masyarakat di kota-kota metropolitan. Tren gaya hidup hedonis setidaknya dapat dilihat melalui tiga aspek, yaitu aktivitas, minat, dan opini yang berkaitan dengan perilaku-perilaku yang dilakukan oleh masyarakat. Setiap perilaku dan gaya hidup tokoh-tokoh dalam novel Antologi Rasa ini merupakan cerminan dari masyarakat yang tinggal di kota metropolitan dalam kehidupan nyata. Bagaimana masyarakat metropolitan berperilaku dalam kehidupan sehari-sehari serta bergaya hidup hedonis merupakan beberapa pokok yang mudah kita lihat pada orang-orang yang tinggal di kota metropolitan.

\section{DAFTAR PUSTAKA}

Akbar, dkk., (2013). Kajian Sosiologi Sastra dan Nilai Pendidikan dalam Novel "Tuan Guru" Karya Salman Faris. Jurnal Pendidikan Bahasa dan Sastra. 1 (1).

Apriliyani, Dian. (2014). Hedonism Reflected in the Beautiful and Damned Novel By F. Scott Fitzgerald. Skripsi. Universitas Brawijaya.

Ardiansyah, MZ. (2017). Bentuk dan Perilaku Hedonisme dalam Novel Edensor Karya Andrea Hirata: Analisis Sosiologi Sastra. Skripsi. Universitas Sumatera Utara.

Boimin dan Wahyuningtyas. (2015). Aspek Sosial dalam Novel Sang Pemimpi Karya Andrea Hirata: Tinjauan Sosiologi Sastra. Jurnal Caraka. 1 (2) Desember 2015.

Dewi, Susanti. (2013). Analisis Struktural dan Sosiologi Sastra terhadap Novel Projo \& Brojo Karya Arswendo Atmowiloto. Skripsi. Universitas Diponegoro.

Dewi, Susi Rosiana. (2011). Tokoh dan Penokohan Alif dalam Novel Negeri 5 Menara Karya A. Fuadi: Sebuah Analisis Objektif. Skripsi. Universitas Indonesia.

Enggel, dkk., (2005). Perilaku Konsumen. Jakarta: Binarupa Aksara.

Hasfian, R. D. (2018). Potret Kemiskinan Dalam Naskah Drama Kampung Kardus Karya Gepeng Nugroho (Kajian Sosiologi Sastra) (Doctoral dissertation, University of Muhammadiyah Malang). 
Hastuti, N. (2018). Novel Bumi Manusia Karya Pramoedya Ananta Toer Kajian Sosiologi Sastra. Humanika, 25(1), 64-74.

Hisabah, Dafir dan Ali Nuke Affandy. (2019). Gaya Hidup Hedonis dalam Novel In Bed With Models Karya Moammar Emka. Jurnal Stilistika. 12 (1) Juni 2019.

Muslimin. (2011). Modernisasi dalam Novel Belenggu Karya Armijin Pane. Jurnal Bahasa, Sastra, dan Budaya. 1 (1).

Natassa, Ika. (2011). Antologi Rasa. Jakarta: Gramedia Pustaka Utama.

Nurgiyantoro, Burhan. (2010). Teori Pengkajian Fiksi. Yogyakarta: Gadjah Mada University Press.

Pradopo, Rachmat Djoko. (2001). Pengkajian Puisi. Yogyakarta: UGM Press.

Prastika, Erliana. (2018). Pengaruh Hidup Hedonismeterhadap Kecurangan Akademik Mahasiswa Bimbingan dan Konseling. Skripsi. Yogyakarta: Universitas Negeri Yogyakarta.

Putra, C. R. W. (2018). Cerminan Zaman dalam Puisi (Tanpa Judul) Karya Wiji Thukul: Kajian Sosiologi Sastra. KEMBARA: Jurnal Keilmuan Bahasa, Sastra, dan Pengajarannya, 4(1).

Rahmawati, dkk. (2018). Emosi Tokoh-Tokoh Sentral dalam Novel Sunset Bersama Rosie Karya Tere Liye. Jurnal Sastra Indonesia. 7 (3) November 2018.

Salfia, Nining. (2015). Nilai Moral dalam Novel 5 CM Karya Donny Dirgantoro. Jurnal Humanika. 15 (3), Desember 2015.

Sipayung, M. E. (2016). Konflik Sosial dalam Novel Maryam karya Okky Madasari: Kajian Sosiologi Sastra. Sintesis, 10(1), 22-34.

Syarifuddin. (2018). Kajian Struktural dan Sosiologi Sastra dalam Novel Seputih Hati Yang Tercabik. Jurnal Kata. 2 (2) Oktober 2018. 